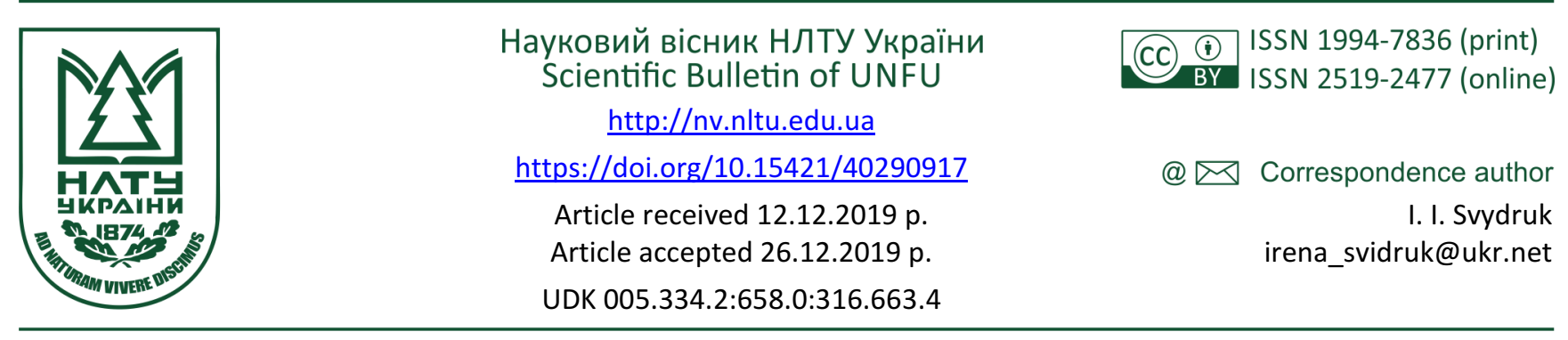

I. I. Свидрук

Львівський торговельно-економічний університет, м. Львів, Украӥна

\title{
УПРАВЛІННЯ КОНФЛІКТАМИ ТА СОЦІАЛЬНИМИ ЕКСПЕКТАЦІЯМИ В ДІЯЛЬНОСТІ ОРГАНІЗАЦІЙ
}

\begin{abstract}
Обгрунтовано потребу активізації ролі ефективного управління конфліктами та соціальними експектаціями членів трудового колективу організації. Наголошено на істотній ролі конфлікту в регуляції діяльності колективу. Оглянуто психологічні причини та детермінанти виникнення міжособистісних, внутрішньогрупових та міжгрупових конфліктів в організації та їхні негативні наслідки. Зазначено низку конструктивних функцій конфліктів у діяльності організацій. Наведено стадії управлінської діагностики конфліктної ситуації. Приділено увагу аналізу суб'єктивного психологічного чинника організаційного конфлікту - опору нововведенням - у взаємозв'язку із психологічними станами особи працівника та методами вирішення конфлікту подолання опору змінам. Доведено, що результативність управлінського впливу значно залежить від соціальних позицій, які займають працівники, їх соціальних ролей в організації. З'ясовано, що неприйняття працівником визначеної для нього професійно-функціональної ролі, однаково як і відсутність ії інтерналізації, спостерігаються коли за змістом та умовами реалізації ця роль не відповідає потребам і самооцінці особистості. Зазначено, що експектаційна невідповідність $\epsilon$ однією з визначальних причин виникнення внутрішньоособистісного конфлікту. Охарактеризовано особливості негативних виявів неправильно обраної соціально-професійної ролі, зокрема синдрому "професійного вигорання". Визначено бажані управлінські впливи для подолання конфлікту. Наведено інструменти психологічної саморегуляції, яка є інтегративною властивістю особистості.
\end{abstract}

Ключові слова: управління; конфлікт; методи вирішення конфліктів; управлінське рішення; соціальні експектації; соціальні ролі.

Вступ. В умовах нестабільності національної економічної системи, необгрунтованого податкового навантаження, нестійких або й взагалі не визначених законодавчо правил функціонування бізнесу, постає питання про потребу переходу управління на самоорганізаційні адаптивні структури, що пристосовуються до зовнішніх збурень за допомогою внутрішньоорганізаційних управлінських інструментів, зокрема ефективних методів управління конфліктами та соціальними експектаціями.

У світовій науковій літературі давно вже обгрунтовано залежність між успішністю управління та соціальними позиціями працівників і соціальними ролями, які вони відіграють в організації.

Аналіз літературних джерел. Активізація значення ефективного управління конфліктами та соціальними експектаціями (далі скорочено УК та CE) зумовлена насамперед високою суспільною потребою у пізнанні конфліктів, які здебільшого виникають через суперечності соціальних очікувань. Зростання важливості цих управлінських інструментів також зумовлено тим, що УК та СЕ допомагає прогнозувати серйозні соціальні потрясіння та запобігати їм, знижувати їхню посиленість, вирішувати суперечності, які виникають між людьми.

Різновекторність розкриття проблематики УК та СЕ зумовлюється багатоаспектністю цих понять. Зокрема науковий напрям розвитку конфліктології зазвичай розглядають через призму проведення наукових конференцій, організації відповідних аналітичних центрів або створення спеціальних підрозділів в інститутах НАН України.

Дослідження соціальних конфліктів в Україні ускладнюється з огляду на те, що сучасна конфліктологічна наука в економічно і соціально високорозвинених європейських країнах впродовж достатньо тривалого періоду розвивалася за умов стабільних і правових суспільств, тоді як для України передумови розвитку конфліктології були не такими сприятливими. Отож, в українському суспільстві конфлікти варто розглядати 3 урахуванням історичних і ментальних особливостей суспільного розвитку. Нові вимоги, зумовлені стрімким входженням вітчизняної економіки у світовий простір, тим більше наголошують на потребі застосування інструментарію УК та СЕ у повному їхньому взаємозв'язку для створення технологій вирішення проблем сучасного менеджменту.

Поняття "соціологія конфлікту" вперше ввів у науковий обіг німецький соціолог Г. Зіммель, дослідження якого стосувалися вивчення стійких форм соціальних відносин. Підкреслюючи важливість конфлікту як однієї з форм суспільного життя і норм соціальної

\section{Інформація про автора:}

Свидрук Ірена Ігорівна, д-р екон. наук, професор, кафедра менеджменту. Email: irena_svidruk@ukr.net; https://orcid.org/0000-0002-3099-6449

Цитування за ДСТУ: Свидрук І. І. Управління конфліктами та соціальними експектаціями в діяльності організацій. Науковий вісник НЛтУ України. 2019, т. 29, № 9. С. 99-104.

Citation APA: Svydruk, I. I. (2019). Conflict and social expectoration management in organizations. Scientific Bulletin of UNFU, 29(9), 99-104. https://doi.org/10.36930/40290917 
взаємодії (Simmel, 2016), він стверджував, що саме перетинання групових егоїстичних інтересів різних соціальних груп здатне дати поштовх для розроблення інструментів пом'якшення конфліктності середовища і стати підгрунтям стійкого демократичного суспільства.

Під час визначення ролі соціальних експектацій необхідно згадати визначення німецького вченого М. Вебера про те, що суспільство є сукупністю груп, які різняться за своїм статусом (Weber, 2013). Логічним є те, що така відмінність $є$ джерелом формування протилежності інтересів та невиправдання очікувань, що і стає причиною більшості соціальних конфліктів.

Розвиваючи ідеї М. Вебера і Г. Зіммеля про загальність і універсальність конфлікту, американський соціолог Л. Козер у своїх працях ретельно дослідив функціональну користь соціального конфлікту (Bodnar, 2010). Розглядаючи конфлікт як один із засобів зняття напруження, він наголошував, що внаслідок вирішення конфліктної ситуації досягається чіткість виявлення групових інтересів, прискорюється структуризація та інституціоналізація соціальних утворень. Як постійне джерело соціальних конфліктів Л. Козер називав непереборний дефіцит ресурсів, влади, цінностей, престижу, що існують у будь-якому суспільстві та в будь-якій організації.

Викладені вище позиції відомих вчених ще раз підтверджують актуальність одночасного дослідження та використання інструментів УК та СЕ для досягнення більшої результативності діяльності працівників організацій.

Об'єкт дослідження - теоретико-методологічні та науково-прикладні засади управління конфліктами та соціальними експектаціями членів трудового колективу організації.

Предмет дослідження - управлінські інструменти аналізу конфліктності та соціальних експектацій працівників організації.

Мета дослідження - оглянути фактори впливу на управління конфліктами та соціальними експектаціями працівників організації та визначити оптимальний управлінський інструментарій в цій царині.

Основні завдання дослідження: 1) обгрунтувати потребу одночасного дослідження процесів управління конфліктами та соціальними експектаціями для досягнення більшої результативності діяльності працівників організацій; 2) окреслити інструменти управлінського впливу для визначення психологічних причин та детермінантів виникнення конфліктів у трудовому колективі; 3) виокремити базові засади управлінського впливу для визначення соціальних позицій працівників та їх соціальних ролей в організації.

Методи дослідження - емпіричні методи наукового дослідження.

Результати дослідження. Соціальна позиція працівника залежить від його професійно-кваліфікаційної характеристики, функціональних обов'язків і визначає його місце в системі управлінських взаємовідносин. Саме соціальною позицією зумовлюється сенсове наповнення соціальних ролей працівника, визначаються його позиція і роль в колективі (Doronina \& Lugova, 2006). Отож, у менеджменті соціальну роль варто розглядати як визначений набір соціальних функцій та стандартів діяльності й поведінки, що реалізуються відповідно до соціальної позиції. Зміст соціальних ролей працівників- новаторів визначається специфічними соціальними очікуваннями (експектаціями), що виникають як безпосередня відповідь на організаційно-технологічні зміни, пов'язані з креативністю діяльності. На постіндустріальному етапі розвитку суспільства не остання роль у виникненні таких експектацій зумовлюється і підвищеними вимогами до соціальної ролі новатора. Комбінування можливих соціальних експектацій зумовлює змістове наповнення соціальних ролей працівників організації. Так, стрімка перебудова економічної системи потребує від працівників вміння продуктивно обробляти великі масиви інформації, отримувати глибокі знання у сфері інноваційних технологій. Виникає об'єктивна потребу у схильних до наукової діяльності працівниках, здатних розробляти та впроваджувати креативні проекти. Також дуже підсилюються вимоги до персоналу щодо володіння іноземними мовами на високому рівні, їх вмінні вести ділові переговори із стейкхолдерами тощо. Водночас чим менший за розмірами трудовий колектив, тим краще працівники орієнтуються щодо персональних креативних можливостей кожного його члена. Отож, експектації набувають більш особистісного характеру. Психологічні особливості кожного індивіда в такому колективі розширюються та взаємодоповнюються, що може як збільшувати ефективність групової діяльності, так і спричиняти міжособистісні конфлікти.

Для розгортання міжособистісних, внутрішньогрупових та міжгрупових конфліктів в організації сьогодні існує безліч стимулів психологічного спрямування. Так, виникнення конфлікту ролей може зумовлюватись недотриманням учасниками творчої групи адекватного розподілу соціальних ролей, зумовлених метою їх спільної діяльності. Іншою причиною його виникнення може бути недосконалість управлінських комунікацій. Наприклад, горизонтальний конфлікт у креативному середовищі зазвичай спричиняється формальним ставленням окремого учасника творчого колективу до реалізації спільного проекту. Водночас вертикальний міжособистісний конфлікт найчастіше виникає у відповідь на прискіпливість керівника до одних підлеглих з одночасною поступливістю до серйозних порушень інших працівників.

Зазвичай основною причиною виникнення внутрішньогрупового конфлікту ролей є психологічна непідготовленість менеджера до управлінських дій в креативному середовищі. До прикладу, можна навести ситуацію, коли управлінський вплив спирається на застарілі догми, тоді як члени творчого колективу ініціюють пошук інноваційних підходів до організації виробничих процесів. Особливістю виникнення міжгрупового конфлікту ролей є його спонтанність і швидке залучення до нього різних підрозділів організації. Однак причини його виникнення зазвичай є легко передбачуваними, адже в підгрунті такого конфлікту завжди лежить блокування можливостей виконання запланованих у проекті завдань певним підрозділом або творчою групою, що виникає через невиконання взаємозалежних завдань іншими підрозділами організації.

Значний енергетичний потенціал конфлікту в діяльності креативного колективу часто стає дієвим інструментом управлінського впливу, підсилюючи його творчі можливості. Однак на практиці частіше спостерігається негативний вплив конфлікту на колектив організації, адже у ньому переважають сильні емоційні пе- 
реживання, що здатні спричиняти психологічний дискомфорт, емоційну нестабільність, невпевненість індивідуума у власних можливостях креативного зростання. Отож, варто систематизувати негативні вияви міжособистісних та внутрішньогрупових конфліктів:

- порушення усталеної системи комунікацій між працівниками;

- перешкода на шляху до досягнення цілей креативного зростання організації;

- послаблення групової єдності;

- загроза особистим інтересам учасників конфліктної ситуації;

- підрив авторитету і позбавлення підтримки з боку інших членів колективу;

- безрезультатне витрачання енергії і ресурсів;

- загроза появи нових конфліктів;

- акцентування на потребі перемоги, а не на вирішенні проблеми;

- зниження ефективності виконання поставленого завдання;

- підвищення плинності кадрів;

- негативні емоційні переживання учасників конфлікту;

- загроза стабільності організації;

- перешкода запровадженню нововведень;

- сприяння виникненню кризових ситуацій (Svydruk, 2015).

В умовах стрімких змін середовища часто відбуваються приховані конфлікти (саботаж, невдоволення) в організації, що є свого роду показником рівня соціальної напруженості в колективі, тому цей вид конфліктів також потребує постійного вивчення і управління.

Конфлікт, як психологічний феномен, подекуди може мати і конструктивне навантаження, викликаючи появу нових ідей. Позитивні особливості внутрішньоособистісного конфлікту проявляються через виникнення процедур самоаналізу особистості, його самовдосконалення і самоосмислення пріоритетності потреб. Міжособистісні та внутрішньогрупові конфлікти, окрім того, дають змогу генерувати свіже сприйняття проблемної ситуації, зумовлюють самореалізацію окремих працівників через можливість оприлюднення власних суджень, що приводить надалі до більшої ефективності групових рішень.

Розвиток конфлікту значно залежить від усвідомлення керівником його значущості та психологічної здатності ним керувати. Управлінню конфліктом повинна передувати стадія його діагностики для визначення основних складових та причин виникнення (рисунок). Визначення суті конфліктної ситуації, іiі адекватне розуміння кожною зі сторін має стати основою прийняття подальшого управлінського рішення.

Виникненню і розвитку конфліктних ситуацій сприяють різні чинники: соціально-психологічні та індивідуально-психологічні детермінанти індивідів; внутрішні та зовнішні суперечності бачення проблеми; неоднорідність психологічних властивостей особистості, зумовлена соціальним досвідом. Виникненню конфліктів також може сприяти недостатній рівень самосвідомості у сприйнятті соціальних ролей.

Важливою умовою ефективної реалізації соціальної ролі виступає їі інтерналізація як ступінь розуміння працівником зовнішніх мотивів i різноаспектного їх проектування в особистісні цілі креативного розвитку. Потрібно наголосити і на актуалізації змістовно близького до інтерналізації явища включення індивіда в творчу діяльність, що визначається мірою відповідності його психологічного стану вимогам творчої самореалізації. Найвищий ступінь включення у творчу діяльність можна визначити як персоніфікацію, тобто максимальну ідентифікацію працівника з творчою діяльністю, яку супроводжує світоглядна перебудова самосприйняття під впливом процесів творчого пошуку (Gibson, 2000).

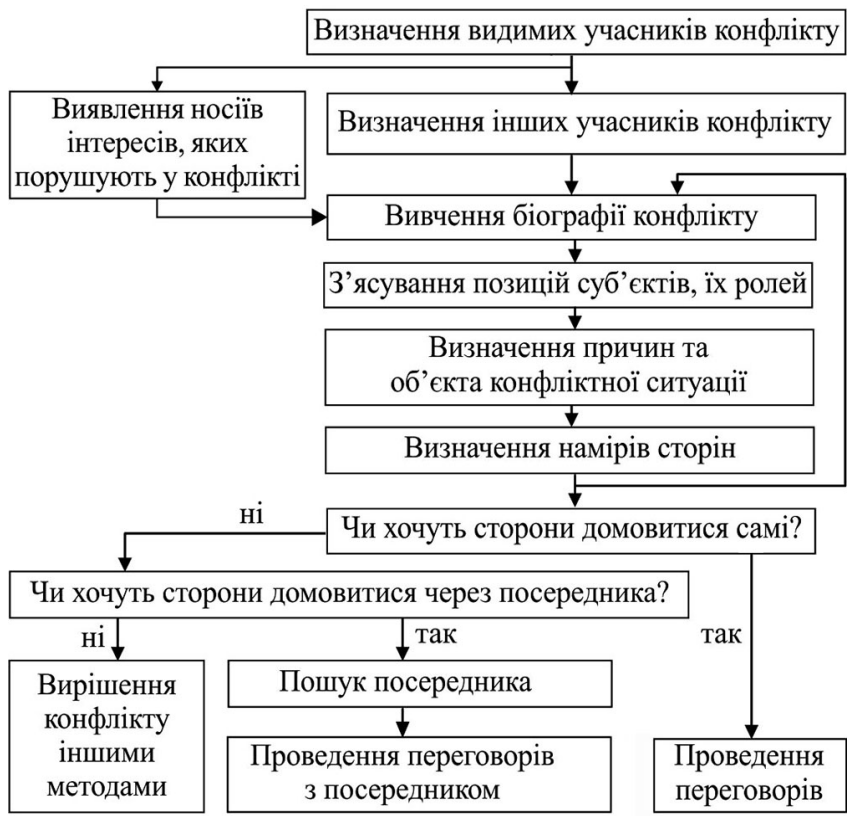

Рисунок. Діагностика конфлікту (Svydruk, 2015)

Самосприйняття працівником нової соціальної ролі зумовлює розвиток особистісних характеристик, здатних позитивно вплинути на його конкурентоспроможність. Зокрема він стає більш організованим і відповідальним, а потреба безперервного саморозвитку викликає розуміння важливості самоосвіти. Високий ступінь включення у креативну діяльність ще більше стимулює розвиток сформованих у процесі виконання проекту особистісних характеристик. Надалі оновлені якості такого працівника можуть навіть трансформуватись у риси характеру й успішно проектуватись в інші сфери його життєдіяльності. Феномен "професійного типу особистості" (Kuznetsova, 2009) можна спостерігати, наприклад, у вигляді творчого ставлення інженера до розроблення нових технологій, пошуку нестандартних методів роботи тощо. Отож, включення у творчу діяльність сприяє розвитку допитливості працівників, зумовлює творчий підхід, який надалі виявлятиметься і в інших видах їх діяльності.

Більше того, повторюване виконання працівником певної соціальної ролі, багаторазове його включення в однотипні виробничі, творчо-пошукові чи управлінські ситуації, часто призводить до виникнення феномену індивідуального професійного стилю, що значно полегшує адаптаційні процеси під час реалізації креативного проекту, збільшує ефективність його діяльності через інтенсифікацію пізнавальних інтересів, що стимулює зростання творчого потенціалу особистості та формує його самоповагу. У такому разі успішність виконання соціальної ролі та усвідомлення ії престижності в зовнішньому оточенні дають змогу індивіду пов'язати досягнення значних результатів із позитивною оцінкою 3 боку оточення, збільшуючи його самооцінку.

Водночас подеколи можна спостерігати і відсутність інтерналізації професійно-функціональних ролей, що зазвичай пов'язано з невідповідністю змісту та умов їх реалізації особистісним потребам і самооцінки працівників. Така експектаційна невідповідність може бути 
причиною виникнення внутрішньоособистісного конфлікту. Варто зауважити і такий можливий негативний вияв неправильно обраної професійно-функціональної ролі, як синдром "професійного вигорання", який призводить до морального і фізичного виснаження працівника, що надалі неминуче позначиться не лише на його психологічному і фізіологічному самопочутті, але й на ефективності професійної діяльності.

Отож, можна стверджувати про наявність певної психологічної дилеми менеджера, яка проявляється в потребі узгодження діаметрально протилежних управлінських впливів на персонал. 3 одного боку, для досягнення цілей креативного розвитку організації менеджер має враховувати амбітні експектації творчих членів колективу, з іншого - обмежувати їхню надмірну творчу активність на тих етапах роботи, на яких $є$ потреба лише в чіткому виконанні інструкцій (Owen, J., 2010). Така одномоментна розбіжність потребує від управлінського персоналу інтуїтивного поєднання наукових і мистецьких підходів, однак подолання описаної психологічної проблеми дасть змогу організації досягти мети креативного розвитку.

Інноваційний розвиток організації потребує істотного оновлення ії глобальних цілей, стратегії розвитку, організації роботи, колективної культури тощо. Управління оновленням соціотехнічної системи передбачає також реорганізацію способів виконання праці (змінними параметрами в такому випадку виступають технології та персонал). Часто таке оновлення супроводжується опором з боку працівників, а подекуди і організації загалом, що супроводжується виникненням різноманітних форм конфліктів. Відкритий опір зазвичай проявляється у формі страйків, зниження продуктивності праці, недбалого ставлення до виконання роботи. Значну небезпеку становлять і приховані конфлікти, ознаками яких можуть стати регулярні спізнення, вимоги переведення на інші ділянки роботи, небажання брати участь у проекті через втрату особистісних стимулів або деморалізацію працівників. Приховані конфлікти здатні збільшувати ризик виникнення помилок у роботі працівників або навіть нещасних випадків, що потребує якомога швидшого їх вирішення.

Зауважимо, що у великих організаціях ризик виникнення конфліктних ситуацій зазвичай є більшим, ніж у вузькоспеціалізованих підрозділах, адже досягнення власних цілей розвитку вони часто вважають пріоритетним відносно загальноорганізаційних. Отож, у такому випадку основною причиною виникнення внутрішньоорганізаційного конфлікту можна вважати розбіжність у сприйнятті групових і загальноорганізаційних цінностей. Об'єктивна оцінка ситуації загальноорганізаційного розвитку у свідомості працівників замінюється суб'єктивним сприйняттям пріоритетності задоволення особистих потреб завдяки використанню сприятливої альтернативи ефективності групи. Подібні мотиви спостерігаються і в конфліктній взаємодії підлеглого, який намагається за будь-яких умов відстоювати власне бачення, та керівника, який наполягає на безумовному виконанні управлінського рішення.

Суб'єктивний психологічний чинник організаційного конфлікту у вигляді опору нововведенням полягає у консерватизмі більшості працівників. Консерватизм є біологічним законом збереження виду, який дав змогу людству вижити. Людям притаманно сприймати нове як певну загрозу, яку варто якомога скоріше ідентифікувати і знешкодити. За статистикою, лише 3-5 \% людей $\epsilon$ інноваційно налаштованими і готовими особисто випробувати новації (Report, 2006). Решті потрібно певний час для звикання і пристосування до змін. Отож, розглянемо різні психологічні стани працівників, які постають перед потребою змін системного характеру:

1. Недостатність довіри. Може проявлятись як несприйняття загального проекту трансформацій, так i його керівників. Одним із фільтрів $є$ перцептуальний захист: працівники з більшою довірою сприймають ситуації, які добре узгоджуються 3 їх суб'єктивним сприйняттям навколишніх реалій. Якщо особа має усталену думку, то переконати iї у зворотному вкрай складно. Психологічно люди захищаються від можливих змін у звичному стилі життя, сприймаючи тільки те, з чим вони погоджуються, та уникаючи того, що може змінити їх світогляд або не узгоджується з їх особистісними цінностями.

2. Страх невідомого. Потреба приймати власні рішення в умовах змін, змінювати стиль та ставлення до діяльності, відмова або зміна у повсякденних звичках тощо спричиняють у свідомості людей побоювання схибити.

3. Небажання втрати влади та впливу. Потреба змін в організації часто призводить до перерозподілу соціальних ролей. Наприклад, підгрунтям впливу особи на колектив був контроль за розподілом інформаційних або матеріальних ресурсів, а реорганізація призвела до ресурсного перерозподілу. Такі працівники чи групи для збереження попереднього впливового становища можуть чинити опір змінам.

4. Особистісні риси характеру. Серед основних особистісних ознак, які можуть стати на заваді запровадженню змін в організації, варто відзначити догматизм як некритичну усталеність особистих переконань, що робить осіб з високим ступенем догматизму схильними до опору змінам. Іншою психологічною причиною конфліктного опору змінам може стати гіпертрофована залежність від думки оточуючих. Такі люди можуть бути нездатними для самостійного оцінювання швидкоплинної ситуації. Отож, вони можуть опиратись трансформаціям до отримання чітких інструкцій та розпоряджень.

5. Звички. Поки конфлікт не посилиться, доти певні індивіди реагують на зміни у звичний для себе спосіб. Варто зауважити, що часто звичка стає однією з форм узгодження власних інтересів із навколишнім середовищем. Тому можливість опору змінам у такому випадку залежить усвідомлення таким працівником особистої вигоди від її зміни. Наприклад, підвищення заробітної плати всім працівникам - не викличе опору, але додаткова умова такого збільшення, що значно погіршить умови праці й відпочинку, - спровокує конфліктну ситуацію (Maslow, 1966).

Отже, основним управлінським завданням у цьому випадку є розроблення механізмів полегшення процесу запровадження змін способом мінімізації опору. Основна психологічна складність тут полягає у потребі порушення наявного балансу соціальних експектацій, збільшуючи тиск змін, зменшуючи (ліквідовуючи) сили опору, в ідеалі- перетворити опір на сприяння запровадженню змін.

Ефективні методи вирішення конфлікту подолання опору змінам у трудовому колективі спираються на виявленні можливостей збільшення креативної компоненти у діяльності. Важлива роль у подоланні опору нале- 
жить якісно налагодженим комунікаціям. Так, менеджеру важливо отримати інформацію щодо звикання працівників до нових умов праці, сутності їх реальних та уявних проблем. Адекватні інформаційні потоки можуть стати якісним інструментом підготовки працівників до нововведень. Безпосередня участь колективу у плануванні та впровадженні змін знімає ризик ігнорування цілей персоналу щодо професійного розвитку через домінування загальноорганізаційних цілей та збільшує ймовірність саморегуляції інтересів працівників, а відповідно - опір з їх боку зменшиться.

Психологічна саморегуляція $є$ інтегративною властивістю особистості, яка об'єднує в собі інтелектуальні, мотиваційні, вольові, емоційні сфери (Gimaeva \& Nikiforova, 2015). Саморегуляцію особистості розглядаємо як єдність соціальних та психологічних проявів його свідомості і самосвідомості. Базисом, необхідним для формування і розвитку системи саморегуляції, $\epsilon$ правильно побудована комунікаційна організація, здатна забезпечити творчі форми розвитку особистості.

Функціональний аспект саморегуляції в структурі подолання опору змінам проявляється за тактичним або стратегічним типами. Тактичний тип передбачає вирішення конфліктної ситуації у стислі терміни, як миттєву реакцію на прояви опору у вигляді конкретного поведінкового акту або вербально. Стратегічний тип саморегуляції пов'язаний з плануванням особистістю цілеспрямованих змін у своїй свідомості. Вирішення внутрішньоособистісного конфлікту грунтується на досвіді самопізнання механізмів управління внутрішніми резервами та сприяє побудові ієрархії мотивів особистості до самореалізації та саморозвитку.

Результати дослідження. Загальнонаукові підходи до цієї проблематики містять у собі управлінський, загальносоціологічний, логічний, загальнопсихологічний. Сучасні умови суспільного життя потребують від управлінської діяльності інтенсивної взаємодії багатьох галузей знань. Сукупність оглянутих у публікації основних методів конфліктології складає іiї методологічну стратегію. Правильність вибору цієї стратегії прямо впливає на ефективність, практичну значущість теоретичних висновків та прикладних управлінських інструментів.

Висновки. Доведено потребу одночасного дослідження та використання інструментів управління конфліктами та соціальними експектаціями для досягнення дешо більшої результативної діяльності працівників організацій.

Через істотну роль конфлікту в регуляції діяльності персоналу, керівництво організації повинно вміти виз- начати психологічні причини та детермінанти виникнення конфліктів у трудовому колективі та їхні негативні наслідки. Для цього рекомендовано використовувати наведену схему розвитку стадій конфліктної ситуації. Важливим $є$ аналіз суб'єктивного психологічного чинника організаційного конфлікту - опору нововведенням, у взаємозв'язку із психологічними станами особи працівника.

Успішність управління визначається соціальними позиціями працівників, їх соціальними ролями в організації. Обгрунтовано потребу управлінської реакції на синдром "професійного вигорання", що надалі дасть змогу отримати бажані управлінські впливи для його подолання та ефективно використовувати інструменти психологічної саморегуляції.

\section{References}

Bodnar, V. (2010). Teoriia pozytyvno-funktsionalnoho konfliktu L. Kozera. [The theory of the positive and functional conflict of L. Koser]. Bulletin of Uzhgorod University, 14, 8-12. [In Ukrainian].

Doronina, M. S., \& Lugova, V. M. (2006). Socio-economic mechanism of motivation of labor behavior. Economics of Development, 2, 18-22. [In Ukrainian].

Gibson, L. J. (2000). Organizatsii: povedeniye, struktura, protsessy. Moscow: INFRA-M, 662 p. [In Russian].

Gimaeva, Yu. A., \& Nikiforova, V. S. (2015). Creativity and motivation of the personality and the relationship between them as the basis of creative activity in graphic designers and marketers. Science and Education, 1, 13-20. [In Ukrainian].

Kuznetsova, N. B. (2009). Personnel of innovative type: essence, value and features of formation in conditions of development of innovative economy. Current Issues in Economics, 6(96), 115-121. [In Ukrainian].

Maslow, A. H. (1966). The Psychology of Science: A Reconnaissance. New York: Harper \& Row.

Owen, J. (2010). Ways to influence others. Moscow: Pretext, 352 p. [In Russian]

Research. (2006). Reporting intellectual capital to augment Research, Development and Innovation in SMEs. Report to the Commission of the High Level Expert Group on RICARDIS. Luxembourg: Office for Official Publications of the European Communities, $64 \mathrm{p}$.

Simmel, G. (2016). Izbrannoye. Problemy sotsiologii. St. Petersburg: Center for Humanitarian Initiatives, 416 p. [In Russian].

Svydruk, I. I. (2015). The essence of creativity and the prerequisites of leadership in creative management. Scientific Bulletin of UNFU, 23(1), 372-379. [In Ukrainian].

Svydruk, I. I. (2015). The role of management psychology in ensuring the economic security of the enterprise. Actual problems of economy and trade in modern conditions of European integration: Materials of scientific conference of teaching staff and graduate students, May 12-13, 2015, (pp. 361-363). Lviv: LKA. [In Ukrainian]. Weber, M. (2013). Hospodarstvo i suspilstvo. Kyiv: Universe, 1112 p. [In Ukrainian].

\section{I. Svydruk \\ Lviv University of Trade and Economics, Lviv, Ukraine}

\section{CONFLICT AND SOCIAL EXPECTORATION MANAGEMENT IN ORGANIZATIONS}

The article is dedicated to enhancing the role of effective conflict management and social expectoration of the organization workforce. Empirical methods of scientific research are used. A number of concepts ("sociology of conflict", "social expectorations", "social role", "internalization", "personification" and others) and their role in the public life and working life of organizations are defined. The combination of possible social expectorations determines the content of social roles of employees of the organization. Individual-psychological characteristics can be expanded or complemented, increasing the effectiveness of collaborative activities or causing interpersonal conflicts. Conflict plays a significant role in the regulation of collective activity. Psychological causes and determinants of interpersonal, intragroup and intergroup conflicts in the organization and their negative consequences are examined. A number of constructive functions of conflicts in the activities of organizations are noted. The stages of management diagnostics of a conflict situation are given. Attention is paid to the analysis of the subjective psychological factor of organizational conflict that is 
resistance to innovations, in relation to the psychological states of the employee personality, and methods of resolving the conflict The success of management is proved to be largely determined by what social positions are occupied by employees, what social roles they play in the organization. It is determined that the rejection of the professional and functional role of the employee, the lack of its internalization are observed when it does not meet the needs and personality of the individual, his or her self-esteem. It has been proved that expectorant discrepancy is capable of causing intrapersonal conflict. The features of the negative manifestation of the wrongly chosen socio-professional role, ie. the syndrome of professional burnout and desirable management influences for its overcoming are characterized. The tools of psychological self-regulation, which is an integrative property of the individual, are presented.

Keywords: management; conflict; methods of conflict resolution; management decision; social expectorations; social roles. 